\title{
Solubility, pH change, and calcium ion release of low solubility endodontic mineral trioxide aggregate
}

\author{
Manar Galal', Dalia Y. Zaki ${ }^{1}$, Mohamed I. Rabie², Samia M. El-Shereif ${ }^{3}$ and Tamer M. Hamdy ${ }^{1 *}$ (D)
}

\begin{abstract}
Background: Insolubility is the main requirement for ideal root end filling material to provide perfect sealing ability. Moreover, alkalinity and bioactivity provide great chance for tissues healing and remineralization. So, the aim of this work was to evaluate the chemical composition, solubility, pH change, and calcium ion release of recently introduced commercial mineral trioxide aggregate (MTA) endodontic repair cement (Harvard, Universal HandMix MTA) compared with ProRoot MTA repair material.

Methods: Solubility was evaluated after 7- and 14-day immersion time of specimens in phosphate buffer saline solution (PBS); the mean weight loss was evaluated and solubility was calculated as a percentage of the weight loss. For assessment of $\mathrm{pH}$ change and calcium ion release polyethylene tubes filled with the materials were soaked in distilled water for 7 and 14 days. Measurement of $\mathrm{pH}$ change was done by analytical $\mathrm{pH}$ meter. Concentrations of calcium ion release were measured using inductively coupled plasma optical emission spectroscopy. Data were statistically analyzed by independent sample $t$ test and paired sample $t$ test at $5 \%$ significance level.

Results: Harvard MTA endodontic cement showed significant lower solubility and higher pH values compared with that of ProRoot MTA. ProRoot MTA exhibited significant higher calcium ion release value after 14 days ( $P$ value $\leq 0.05)$.

Conclusion: Harvard, Universal HandMix MTA repair cement with its different chemical composition; exhibits a low solubility with enhanced alkaline $\mathrm{pH}$ value compared to ProRoot MTA repair material.
\end{abstract}

Keywords: Harvard MTA, ProRoot MTA, Solubility, pH change, Calcium ion release, XRD analysis

\section{Background}

MTA is a calcium silicate-based cement, consists mainly of mixture of dicalcium silicate, tricalcium silicate, tricalcium aluminate, and a radiopacifier (Macwan and Deshpande 2014; Espir et al. 2016). Recently, efforts are directed to produce novel bioactive dental materials promoting hard tissue formation (Sarkar et al. 2005; Hamdy et al. 2019).

Nowadays, MTA has evolved as a most recommended material of choice used for several endodontic

\footnotetext{
* Correspondence: dr_tamer_hamdy@yahoo.com

${ }^{1}$ Restorative and Dental Materials Department, National Research Centre (NRC), El Bohouth St., Giza 12622, Dokki, Egypt

Full list of author information is available at the end of the article
}

treatments such as pulp capping, root canal filling, repair of root canal perforation, and as root end filling material (Toptanci et al. 2013). This is due to its superior properties regarding biocompatibility, antibacterial activity, their ability to induce hard tissues formation through locally raising the $\mathrm{pH}$ to alkaline values, and the capability to release of calcium ions (Gandolfi et al. 2014; Prasad and Naik 2017). Moreover, it can set even in the presence of moisture (Nagmode et al. 2016). MTA proved to form chemical bonding with hard tooth structure forming intimate hermetic seal (Surya Raghavendra et al. 2017) and encourage healing of periapical tissues (Zaki et al. 2018).

Insolubility is a crucial feature in endodontic materials to provide intimate seal between tooth wall and

\section{Springer Open}

(0) The Author(s). 2020 Open Access This article is licensed under a Creative Commons Attribution 4.0 International License, which permits use, sharing, adaptation, distribution and reproduction in any medium or format, as long as you give appropriate credit to the original author(s) and the source, provide a link to the Creative Commons licence, and indicate if changes were made. The images or other third party material in this article are included in the article's Creative Commons licence, unless indicated otherwise in a credit line to the material. If material is not included in the article's Creative Commons licence and your intended use is not permitted by statutory regulation or exceeds the permitted use, you will need to obtain permission directly from the copyright holder. To view a copy of this licence, visit http://creativecommons.org/licenses/by/4.0/. 
restoration for subsequent successful root canal treatments (Torres et al. 2019). Despite of the previously mentioned superior properties of MTA, their high solubility rate limits the clinical success rate of endodontic MTA (Espir et al. 2016; Surya Raghavendra et al. 2017). The solubility of root canal sealers should be less than $3 \%$ according to the International Organization for Standardization (ISO) (ISO 6876:2012 2012) and American Dental Association (ADA) ( 1984).

Recently, Harvard MTA (Universal HandMix) has been introduced as repair cement based on mineral oxides and bismuth oxide. The manufacturer claims that, after mixing of powder and liquid, the set cement has a high $\mathrm{pH}$ value (more than 11) and minimum solubility in tissue fluid. Thus, the aim of the current study was to investigate the chemical composition of Harvard, Universal HandMix MTA repair cement and correlate it with its solubility, $\mathrm{pH}$ change, and calcium ion release. The obtained results were compared with that of the ProRoot MTA repair material.

\section{Materials and methods}

Two commercial MTA-based endodontic repair cements were used in this study. Harvard MTA, Universal HandMix (Harvard Dental International, Hoppegarten, Germany) and ProRoot MTA (Dentsply Tulsa Dental Products, Tulsa, USA) as a control.

\section{XRD analysis}

The chemical composition of the two tested cements was examined by $\mathrm{X}$-ray powder diffraction analysis (XRD) (Bruker-AXS D8 X-ray diffractometer, Germany). XRD data were collected in the $2 \theta$ range $0-60^{\circ}$. The obtained XRD patterns were compared with model patterns on the Joint Committee on Powder Diffraction Standard (JCPDS) databases.

\section{Specimen preparation}

The two endodontic cements were prepared according to the manufacturer's instructions $(1 \mathrm{~g}$ powder was mixed with $0.33 \mathrm{ml}$ distilled water). Mixing was done using stainless steel spatula to avoid inclusion of air bubble. Cement was then condensed into the specially prepared mold for each test type.

\section{Analytic test \\ Solubility}

Specimens $(n=5)$ were prepared using stainless steel ring mold with an internal diameter of $(10 \pm 1 \mathrm{~mm})$ and a height of $(2 \pm 0.1 \mathrm{~mm})$ was prepared and weighted using analytical balance (Adam equipment 4 digits precision weighing balance, UK). The mixed MTA cements were placed in the ring mold and allowed to set at $37^{\circ} \mathrm{C}$ in an incubator (CBM 2431/V, Italy), for a period more than $50 \%$ of the final setting time $(24 \mathrm{~h})$. Each ring mold with MTA specimen was initially weighed to determine the initial mass. Specimens were then immediately immersed in $100 \mathrm{ml}$ PBS $\left(1.7 \mathrm{~g} \quad \mathrm{KH}_{2} \mathrm{PO}_{4}, 11.8 \mathrm{~g}\right.$ $\mathrm{Na}_{2} \mathrm{HPO}_{4}, 80.0 \mathrm{~g} \mathrm{NaCl}$, and $2.0 \mathrm{~g} \mathrm{KCl}$ in $10 \mathrm{~L}$ of $\mathrm{H}_{2} \mathrm{O}$ ) at $37^{\circ} \mathrm{C}$ and $\mathrm{pH}=7.2$.

Rings filled with MTA were kept in PBS in the incubator for 7 and 14 days. Each ring mold filled with MTA specimen was then removed, washed with distilled water, and dried with drier paper. The weights of the mold rings with MTA specimen were measured and the weight differences were calculated. The solubility of the cement was calculated as a percentage of weight loss (Shojaee et al. 2015; Poggio et al. 2017; Torres et al. 2018).

\section{$\mathrm{pH}$ change and calcium ion release}

Each cement type was placed in a polyethylene tubes $(2$ $\mathrm{mm}$ in diameter) $(n=5)$, soaked in $10 \mathrm{ml}$ distilled water, and incubated for 7 and 14 days at $37^{\circ} \mathrm{C}$. Measurement of $\mathrm{pH}$ change was done by $\mathrm{pH}$ meter (Jen-way 3510 bench $\mathrm{pH}$ meter, UK). The concentrations of calcium ion release were measured using inductively coupled plasma optical emission spectroscopy (ICP-OES) (Ultima 2 ICP, Horiba, USA) (Amini Ghazvini et al. 2009).

\section{Statistical analysis}

The statistical analysis was performed using Statistical Package for the Social Sciences (SPSS, IBM, USA). Independent sample $t$ test was used to compare mean solubility values between two MTA types (Harvard and ProRoot). The significance level was set at $P \leq 0.05$. Similarly, the same test was used to compare results of $\mathrm{pH}$ as well as calcium release between the two groups.

To assess the effect of time within each MTA type, paired sample $t$ test was used to compare the solubility values detected in day 7 and after 1 week (detected in day 14) for the same specimens. Similarly, the $\mathrm{pH}$ and calcium ion release values by time were statistically analyzed using paired sample $t$ test within each MTA type.

\section{Results}

XRD results revealed the presence of two different types of calcium silicates in Harvard MTA repair cement including $75 \% \mathrm{Ca}_{3} \mathrm{Mg}\left(\mathrm{SiO}_{4}\right)_{2}$ (Merwinite) and $20 \% \mathrm{Ca}_{3}$ $\left(\mathrm{SiO}_{4}\right)$ O (Hatrurite). On the other hand, ProRoot MTA type formed of $90 \%$ Hatrurite. Bismite $\left(\mathrm{Bi}_{2} \mathrm{O}_{3}\right)$ (5 and $10 \%)$ as a radiopacifier was found in both Harvard MTA and ProRoot MTA types respectively (Figs. 1 and 2).

The results of solubility, $\mathrm{pH}$ change, and calcium ion release values of the two tested MTA endodontic repair cements after 7 and 14 days are illustrated in Tables 1, 2 and 3. A significant lower solubility and higher $\mathrm{pH}$ values were revealed in Harvard MTA type compared to 


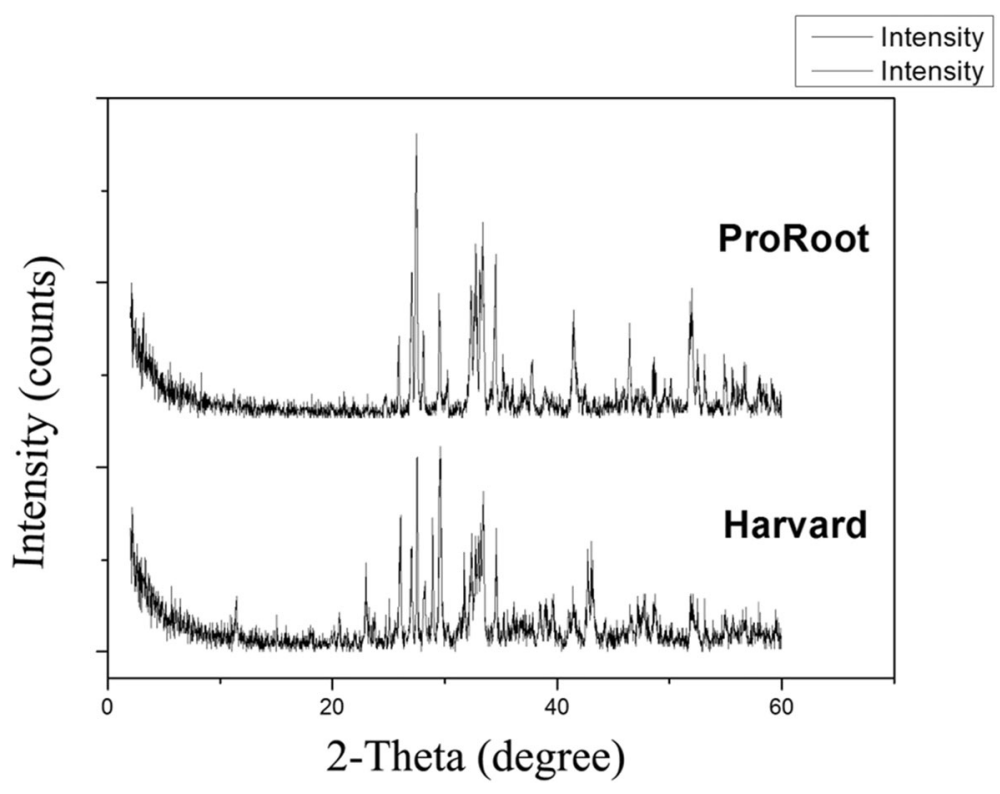

Fig. 1 XRD patterns of Harvard and ProRoot endodontic cements

that of ProRoot $(P<0.05)$. On the other hand, no significant changes in solubility and $\mathrm{pH}$ values were found in Harvard MTA after 7- and 14-day immersion time. Whereas, ProRoot cement showed a significant increase in solubility after 14 than 7 -day immersion time. The calcium ion release after 7-day immersion time was significantly higher in Harvard. However after 14 days, the ProRoot showed significant higher values of $\mathrm{Ca}$ ion release when compared to that of Harvard type which significantly decreased after 14-day immersion time.

\section{Discussion}

Recently, a diversity of MTA-based endodontic repair cements has been introduced to improve root canal treatment (Yang et al. 2018). The manufacturer of Harvard MTA Universal HandMix material claimed their low solubility and high $\mathrm{pH}$ value (more than 11). During this study, XRD analysis of Harvard MTA and ProRoot MTA together with solubility, $\mathrm{pH}$ changes, and $\mathrm{Ca}$ ion release evaluation was done to correlate the chemical composition with the tested properties. ProRoot MTA endodontic repair cement was used in this study as control gold standard due to its well-established superior outcomes (Schmitt et al. 2001; Torabinejad et al. 2018).

Insolubility is a crucial factor for ideal requirement of root end filling material (Shojaee et al. 2015). Following ISO 6876 for the solubility test, the amount of cements that was solubilized was determined via measurement of the difference between the initial and final weights. Such values must be near $0.1 \%$ and must not exceed 3\% (ISO 6876:2012 2012). Phosphate buffer saline solution was used in the current study as a storage media to simulate the clinical conditions due to its comparable composition to dentinal fluid (Saghiri et al. 2011).

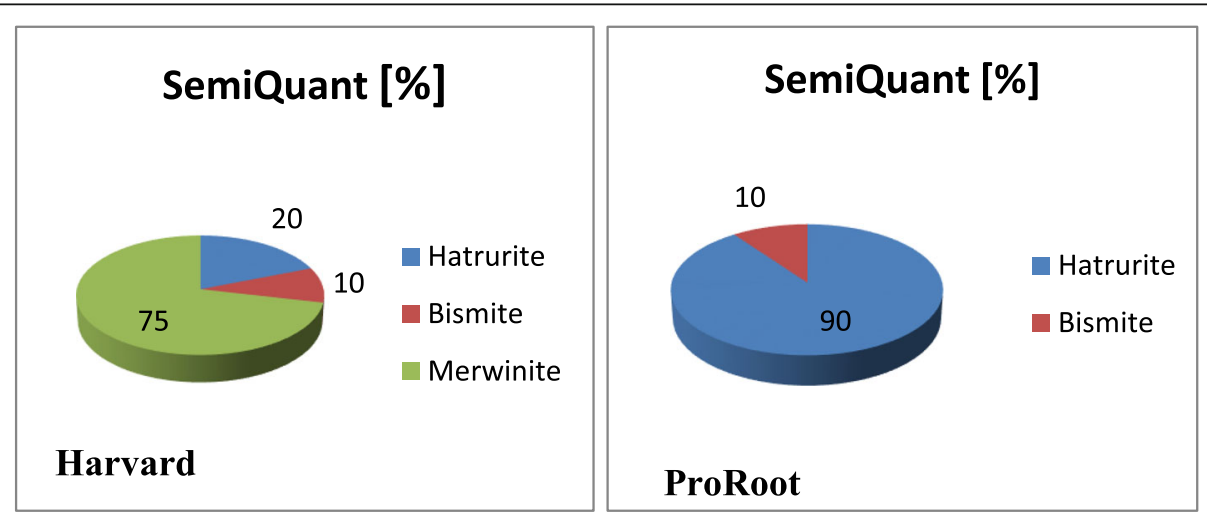

Fig. 2 Minerals' percentage of XRD analysis for Harvard and ProRoot endodontic cements 
Table 1 The mean and standard deviation values of the changes in solubility (percent mean weight changes) of the two tested cements stored in STF at 7 and 14 days

\begin{tabular}{llll}
\hline Test group & Harvard & ProRoot & $\boldsymbol{P}$ value \\
\hline Solubility \% after 7 days & $0.3 \pm 0.02$ & $0.85 \pm 0.01$ & $\leq 0.001^{*}$ \\
Solubility \% after 14 days & $0.32 \pm 0.01$ & $0.9 \pm 0.01$ & $\leq 0.001^{*}$ \\
$\boldsymbol{P}$ value & 0.14 & $0.001^{*}$ & \\
\hline * & & &
\end{tabular}

${ }^{*}$ significant $(P<0.05)$

An alkaline $\mathrm{pH}$ environment is a significant issue that encourages the healing of dental tissue and remineralization (Amini Ghazvini et al. 2009). The bioactivity of endodontic material could be estimated from their ability to release calcium ions and maintaining a high $\mathrm{pH}$ value (Sarkar et al. 2005).

XRD analysis results revealed the presence of Bismite (bismuth oxide) as a radiopacifier in both tested material types (Bortoluzzi et al. 2009; Torabinejad et al. 2018). XRD analysis results also revealed a difference in composition between the tested materials, where Harvard type composed mainly of $75 \mathrm{wt} \%$ Merwinite (calcium magnesium orthosilicate) and $20 \mathrm{wt} \%$ Hatrurite mineral. On the other hand, Hatrurite mineral content in ProRoot constitutes $90 \%$ of the composition. Merwinite was probably used in Harvard type due to its proved excellent bioactivity, lower solubility, and appropriate mechanical properties (Ou et al. 2008; Hafezi-Ardakani et al. 2011; Hafezi et al. 2013).

The lower solubility of Harvard MTA endodontic cement than ProRoot endodontic cement may be attributed to the presence of Merwinite as a major component in Harvard endodontic cement (HafeziArdakani et al. 2011). Lower solubility of Merwinite may be due to the pronounced slower dissolution tendency of magnesium compared to calcium especially in alkaline pH (Hafezi-Ardakani et al. 2011). ProRoot revealed a significant increase in solubility after 14 days than 7 days; this may be due to the high hydration reactivity of $\mathrm{Ca}_{3} \mathrm{SiO}_{5}$ (Hatrurite) which forms the main composition of ProRoot cement (Sokol et al. 2019).

MTA-based endodontic sealers have bioactive properties; thus, in contact with phosphate buffer saline solution, it dissociates and releases its major cationic components. Calcium ions are the most dominant ion released from MTA when stored in PBS (Espir et al.

Table 2 Means and standard deviations of $\mathrm{pH}$ values after 7 and 14 days for the two tested cements stored in distilled water

\begin{tabular}{llll}
\hline Test group & Harvard & ProRoot & $\boldsymbol{P}$ value \\
\hline pH after $\mathbf{7}$ days & $12.56 \pm 0.07$ & $11.97 \pm 0.1$ & $\leq 0.001^{*}$ \\
$\mathbf{p H}$ after 14 days & $12.52 \pm 0.01$ & $12.04 \pm 0.02$ & $\leq 0.001^{*}$ \\
$\boldsymbol{P}$ value & 0.3 & 0.3 & \\
\hline
\end{tabular}

${ }^{*}$ significant $(P<0.05)$
Table 3 Means and standard deviations of calcium ion release values after 7 and 14 days for the two tested cements stored in distilled water

\begin{tabular}{llll}
\hline Test group & Harvard & ProRoot & $\boldsymbol{P}$ value \\
\hline Ca ion release after 7 days & $242.8 \pm 1.8$ & $239 \pm 1.6$ & $0.007^{*}$ \\
Ca ion release after 14 days & $47.8 \pm 1.9$ & $65.6 \pm 1.1$ & $\leq 0.001^{*}$ \\
$\boldsymbol{P}$ value & $\leq 0.001^{*}$ & $\leq 0.001^{*}$ & \\
\hline *significant $(P<0.05)$ & & &
\end{tabular}

2016). Calcium ion release depends on the composition of the mineral particles of the cement responsible for water solubility and diffusion (Gandolfi et al. 2015). The higher $\mathrm{Ca}$ ion release after 7 days in Harvard compared to ProRoot endodontic cement may be attributed to the higher total calcium concentration in the composition of Harvard than ProRoot endodontic cement. However, the significant decrease in $\mathrm{Ca}$ ion release after 14 days in both types of cements may be the result of the decrease in $\mathrm{Ca}$ ion dissolution by time. These findings coincide with that of Fridland and Rosado (2005) which demonstrated that the ability of MTA-based cements to partially release calcium ions into an aqueous environment was decreased over time (Fridland and Rosado 2005).

The higher alkalinity of the Harvard MTA endodontic cement than ProRoot may be due to their higher $\mathrm{Ca}$ ion release concentration (Poggio et al. 2017). Moreover, Harvard showed no significant changes in $\mathrm{pH}$ after 7 and 14-day immersion time which may be correlated to the minimum $\mathrm{Ca}$ ion release over time.

\section{Conclusion}

The innovative endodontic cement (Harvard, Universal HandMix MTA) exhibits a low solubility with enhanced alkaline $\mathrm{pH}$ value and calcium ion release due to the presence of Merwinite as a major constituent compared to ProRoot MTA repair material.

\section{Abbreviations}

MTA: Mineral trioxide aggregate; PBS: Phosphate buffer saline solution; ISO: International Organization for Standardization; ADA: American Dental Association; XRD: X-ray powder diffraction; JCPDS: Joint Committee on Powder Diffraction Standard; ICP-OES: Inductively coupled plasma optical emission spectroscopy; SPSS: Statistical Package for the Social Sciences

\section{Acknowledgements}

Thanks are due to the National Research Centre for allowing the use of the Dental materials laboratory facilities.

Authors' contributions

All authors contributed to the conception and design of the study. Manar Gala and Tamer M. Hamdy performed the experimental work. Tamer M. Hamdy interpreted the analyzed data, wrote, and corresponded the manuscript. Dalia Y. Zaki revised and reviewed the draft manuscript. All authors read and approved the final manuscript. 


\section{Availability of data and materials}

All data generated or analyzed during this study are included in this published article.

\section{Ethics approval and consent to participate}

Not applicable.

\section{Consent for publication}

Not applicable.

\section{Competing interests}

The authors declare that they have no competing interests.

\section{Author details}

${ }^{1}$ Restorative and Dental Materials Department, National Research Centre (NRC), El Bohouth St., Giza 12622, Dokki, Egypt. ${ }^{2}$ Endodontic department, College of Dentistry, Suez Canal University, Ismailia, Egypt. ${ }^{3}$ Endodontic department, Faculty of Dentistry, Cairo University, Giza, Dokki, Egypt.

Received: 16 January 2020 Accepted: 18 March 2020

Published online: 24 March 2020

\section{References}

Amini Ghazvini S, Abdo Tabrizi M, Kobarfard F, Akbarzadeh Baghban A, Asgary S (2009) Ion release and pH of a new endodontic cement, MTA and Portland cement. Iran Endod J 4(2):74-78 Available from: http://www.ncbi.nIm.nih. gov/pubmed/23940490\%0Ahttp:/www.pubmedcentral.nih.gov/articlerender. fcgi?artid=PMC3740134

ANSI/ADA (1984) Specification no. 57 for endodontic filling materials. J Am Dent Assoc 108(1):88

Bortoluzzi EA, Broon NJ, Bramante CM, Felippe WT, Tanomaru Filho M, Esberard RM (2009) The influence of calcium chloride on the setting time, solubility, disintegration, and $\mathrm{pH}$ of mineral trioxide aggregate and white Portland cement with a radiopacifier. J Endod. 35(4):550-554

Espir CG, Guerreiro-Tanomaru JM, Spin-Neto R, Chávezandrade GM, Berbert FLCV Tanomaru-Filho M (2016) Solubility and bacterial sealing ability of MTA and root-end filling materials. J Appl Oral Sci. 24(2):121-125

Fridland M, Rosado R (2005) MTA solubility: a long term study. J Endod. 31(5): 376-379

Gandolfi MG, Siboni F, Botero T, Bossù M, Riccitiello F, Prati C (2015) Calcium silicate and calcium hydroxide materials for pulp capping: biointeractivity, porosity, solubility and bioactivity of current formulations. J Appl Biomater Funct Mater. 13(1):1-18

Gandolfi MG, Siboni F, Primus CM, Prati C (2014) Ion release, porosity, solubility, and bioactivity of MTA plus tricalcium silicate. J Endod. 40(10):1632-1637

Hafezi M, Abbasi-Shahni M, Zamanian A, Hesaraki S (2013) Preparation and characterization of whitlockite-merwinite nanocomposite. J Ceram Process Res. 14(1):96-99

Hafezi-Ardakani M, Moztarzadeh F, Rabiee M, Talebi AR (2011) Synthesis and characterization of nanocrystalline merwinite (Ca $3 \mathrm{Mg}(\mathrm{SiO} 4) 2)$ via sol-gel method. Ceram Int. 37(1):175-180

Hamdy TM, Mousa SMA, Sherief MA (2019) Effect of incorporation of lanthanum and cerium-doped hydroxyapatite on acrylic bone cement produced from phosphogypsum waste. Egypt I Chem Available from: https:/ejchem. journals.ekb.eg/article_56188.html

ISO 6876:2012 (2012) Dentistry -- Root canal sealing materials. Int Organ Stand 9

Macwan C, Deshpande A (2014) Mineral trioxide aggregate (MTA) in dentistry: a review of literature. J Oral Res Rev. 6(2):71

Nagmode PS, Satpute AB, Patel AV, Ladhe PL (2016) The effect of mineral trioxide aggregate on the periapical tissues after unintentional extrusion beyond the apical foramen. Case Rep Dent 2016

Ou J, Kang Y, Huang Z, Chen X, Wu J, Xiao R et al (2008) Preparation and in vitro bioactivity of novel merwinite ceramic. Biomed Mater 3(1)

Poggio C, Dagna A, Ceci M, Meravini MV, Colombo M, Pietrocola G (2017) Solubility and $\mathrm{pH}$ of bioceramic root canal sealers: a comparative study. J Clin Exp Dent. 9(10):e1189-e1194

Prasad BSK, Naik CT (2017) Mineral trioxide aggregate in endodontics. Int J Appl Dent Sci. 3(1):71-75

Saghiri MA, Ricci J, Joupari MD, Aeinehchi M, Ahmadi K, Bahramian N (2011) A comparative study of MTA solubility in various media. Iran Endod J. 6(1):21-24
Sarkar NK, Caicedo R, Ritwik P, Moiseyeva R, Kawashima I (2005) Physicochemical basis of the biologic properties of mineral trioxide aggregate. J Endod. 31(2): $97-100$

Schmitt D, Lee J, Bogen G (2001) Multifaceted use of ProRoot ${ }^{\mathrm{TM}}$ MTA root canal repair material. Pediatr Dent. 23(4):326-330

Shojaee NS, Sahebi S, Karami E, Sobhnamayan F (2015) Solubility of two root-end filling materials over different time periods in synthetic tissue fluid: a comparative study. J Dent (Shiraz, Iran) 16(3):189-18994

Sokol EV, Kokh SN, Sharygin W, Danilovsky VA, Seryotkin W, Liferovich R et al (2019) Mineralogical diversity of ca2 sio4-bearing combustion metamorphic rocks in the hatrurim basin: implications for storage and partitioning of elements in oil shale clinkering. Minerals 9(8)

Surya Raghavendra S, Jadhav GR, Gathani KM, Kotadia P (2017) Bioceramics in endodontics - a review. J Istanbul Univ Fac Dent $51(0)$

Toptanci IR, Dalli M, Colak H (2013) The composition and biologic actions of mineral trioxide aggregate: a review. Konuralp Tip Derg. 5(2):70-74

Torabinejad M, Parirokh M, Dummer PMH (2018) Mineral trioxide aggregate and other bioactive endodontic cements: an updated overview - part II: other clinical applications and complications. Int Endodontic J 51:284-317

Torres FFE, Guerreiro-Tanomaru JM, Bosso-Martelo R, Chavez-Andrade GM, Tanomaru FM (2018) Solubility, porosity and fluid uptake of calcium silicatebased cements. J Appl Oral Sci. 26:e20170465

Torres FFE, Guerreiro-Tanomaru JM, Bosso-Martelo R, Espir CG, Camilleri J, Tanomaru-Filho M (2019) Solubility, porosity, dimensional and volumetric change of endodontic sealers. Braz Dent J. 30(4):368-373

Yang DK, Kim S, Park JW, Kim E, Shin SJ (2018) Different setting conditions affect surface characteristics and microhardness of calcium silicate-based sealers. Scanning. 2018

Zaki DY, Zaazou MH, Khallaf ME, Hamdy TM (2018) In vivo comparative evaluation of periapical healing in response to a calcium silicate and calcium hydroxide based endodontic sealers. Open Access Maced J Med Sci. 6(8): 1475-1479

\section{Publisher's Note}

Springer Nature remains neutral with regard to jurisdictional claims in published maps and institutional affiliations.

\section{Submit your manuscript to a SpringerOpen ${ }^{\circ}$ journal and benefit from:}

- Convenient online submission

- Rigorous peer review

- Open access: articles freely available online

- High visibility within the field

- Retaining the copyright to your article

Submit your next manuscript at $\boldsymbol{\nabla}$ springeropen.com 